\title{
Novel Molecular Building Blocks Based on the Boradiazaindacene Chromophore: Applications in Fluorescent Metallosupramolecular Coordination Polymers
}

\author{
Ö. Altan Bozdemir, ${ }^{[a]}$ Onur Büyükcakir, ${ }^{[a, b]}$ and Engin U. Akkaya* ${ }^{[a]}$
}

\begin{abstract}
We designed and synthesized novel boradiazaindacene (Bodipy) derivatives that are appropriately functionalized for metal-ion-mediated supramolecular polymerization. Thus, ligands for 2-terpyridyl-, 2,6-terpyridyl-, and bipyridyl-functionalized Bodipy dyes were synthesized through Sonogashira couplings. These fluorescent building blocks are responsive to metal ions in a stoichiometry-dependent
\end{abstract}

manner. Octahedral coordinating metal ions such as $\mathrm{Zn}^{\mathrm{II}}$ result in polymerization at a stoichiometry corresponding to two terpyridyl ligands to one $\mathrm{Zn}^{\mathrm{II}}$ ion. However, at increased metal ion

Keywords: coordination polymers • dyes/pigments - polymerization • self-assembly $\quad$. Sonogashira coupling concentrations, the dynamic equilibria are re-established in such a way that the monomeric metal complex dominates. The position of equilibria can easily be monitored by ${ }^{1} \mathrm{H} \mathrm{NMR}$ and fluorescence spectroscopies. As expected, although open-shell $\mathrm{Fe}^{\mathrm{II}}$ ions form similar complex structures, these cations quench the fluorescence emission of all four functionalized Bodipy ligands.

\section{Introduction}

Coordination polymers represent a distinct group of supramolecular polymers,${ }^{[1-6]}$ which have attracted great attention in recent years. ${ }^{[7-12]}$ The degree of polymerization in such polymers is primarily controlled by the concentration of the building blocks in solution and the strength of interaction between the ligand and the metal ion. The dynamic nature of the equilibria governing the extent of polymerization provides enormous potential in manipulating the macroscopic properties of these polymers, whether in solution or in other phases. Recent studies in the groups of Würthner ${ }^{[13-15]}$ and Schubert ${ }^{[16,17]}$ established the viability of the terpyridylmetal coordinative bond as a promising strategy for the preparation of such self-assembled supramolecular polymers. In these studies, fluorescent supramolecular coordina-

[a] Dr. Ö. A. Bozdemir, O. Büyükcakir, Prof. Dr. E. U. Akkaya Department of Chemistry and UNAM-Institute of Materials Science and Nanotechnology

Bilkent University, 06800 Ankara (Turkey)

Fax: (+90)312-266-4068

E-mail: eua@fen.bilkent.edu.tr

[b] O. Büyükcakir

Department of Chemisty, Middle East Technical University 06531 Ankara (Turkey)

Supporting information for this article is available on the WWW under http://dx.doi.org/10.1002/chem.200802538. tion polymers were obtained by utilizing terpyridyl- $\mathrm{Zn}^{\mathrm{II}}$ coordination.

Boradiazaindacene ${ }^{[18-19]}$ dyes (also known as bodipy dyes, boron-dipyrrin dyes, and BDPs) are bright fluorophores with many desirable properties, including very versatile chemistry of the parent fluorophore. ${ }^{[20-23]}$ In recent years, there has been a flurry of activity investigating many derivatives and numerous applications of these dyes. Among these, fluorescent chemosensors, ${ }^{[24-27]}$ molecular logic gates, ${ }^{[28]}$ fluorescent organogels, ${ }^{[29]}$ sensitizers in dye-sensitized solar cells, ${ }^{[30,31]}$ cellular imaging ${ }^{[32]}$ and applications in photodynamic therapy ${ }^{[33,34]}$ are particularly noteworthy. There have also been previous reports of bipyridyl ${ }^{[35,36]}$ and terpyridyl ${ }^{[37-39]}$ derivatives of bodipy dyes and their $\mathrm{Zn}^{\mathrm{II}}$ complexes, although the monomeric derivatives were not designed for self-assembled polymerization. Herein, we report 2- and 2,6-derivatized bodipy dyes with one or two ligands per bodipy unit, placed on opposite ends of the fluorophore core. In the case of the bis(terpyridyl) derivative, clear signals of polymerization are observed by using ${ }^{1} \mathrm{H}$ NMR spectroscopy upon gradual addition of $\mathrm{Zn}^{\mathrm{II}}$. The additional data obtained from the monoterpyridyl derivative also corroborates the interpretation of the spectral changes observed by using NMR spectroscopy. In addition, the ligand is attached to the bodipy core through triple bonds, and any changes in charge density distribution are transmitted to the core. The result is a significant enhancement in 
the emission intensity upon $\mathrm{Zn}^{\mathrm{II}}$ binding, which is accompanied by a small blueshift in the absorption spectrum. Thus, formation of the coordination polymers were also evidenced by fluorescence changes of the fluorophores. To the best of our knowledge, signaling of metal-ion-mediated polymerization through a clear and observable change in the emission intensity was unprecedented.

\section{Results and Discussion}

Synthesis of the building blocks: To improve solubility in organic solvents, our synthetic approach required the initial synthesis of a bodipy derivative with 3,5-bis(decyloxy)phenyl groups at the meso positions. We started our synthesis with 3,5-bis(decyloxy)benzaldehyde 1, which can be obtained by a two-step conversion from commercially available 3,5-dihydroxybenzyl alcohol. Standard procedures yielded bright green emitting bodipy dye $\mathbf{2}$ in $30 \%$ yield. Addition of different molar ratios of $\mathrm{I}_{2} / \mathrm{HIO}_{3}$ to bodipy 2 resulted in either monoiodinated $\mathbf{3}$, or diiodinated $\mathbf{4}$ bodipy derivatives. ${ }^{[40]} \mathrm{Li}$ gands were tethered to the fluorophore unit through Sonogashira couplings using either 4-ethynylphenylterpyridyl or bis(ethynylbipyridyl), both of which were described by Ziessel and co-workers. ${ }^{[39,41]}$ The reactions proceeded smoothly, yielding target compounds 5, 6, 7, and 8. Maximal absorption peaks showed larger redshifts in the cases of 2,6-bissubstituted products (571 and $577 \mathrm{~nm}, \mathbf{8}$ and 7 respectively). Compound $\mathbf{6}$ was designed as the monomeric building block for a fluorescent supramolecular coordination polymer. Compound $\mathbf{5}$ is a reference compound, expected to assist us in identifying spectral changes on polymer formation. Bipyridyl derivatives $\mathbf{7}$ and $\mathbf{8}$ are different types of building block that might be useful in the construction of gridlike structures and metal-ion-coordination-mediated energy transfer and light-harvesting systems. Compound 8 (Scheme 1) is

\footnotetext{
Abstract in Turkish: Bu çalışmada, metal iyonları aracılı̆̆ıyla supramoleküler polimerizasyon için uygun şekilde fonksiyonlandırılmış yeni boradiazaindasen (Bodipy) türevleri tasarlanmış ve sentezlenmiştir. Bu amaçla, ligand olarak Sonogashira reaksiyonu ile 2- ve 2,6-terpiridil ve bipiridil grupların içeren Bodipy boyarmaddeleri sentezlenmistitir. Bu floresan yapı blokları stokiyometriye bağlı bir biçimde metal iyonlartna duyarlılı gösterirler. Zn ${ }^{I I}$ gibi oktahedral koordinasyon eğilimi olan metal iyonlarl, iki terpiridil ligandına bir $\mathrm{Zn}^{I I}$ iyonu tekabül edecek bir stokiyometride polimerizasyona yol açmaktadırlar. Bununla beraber, yüksek metal iyonu derişimlerinde monomerik metal kompleksinin baskın olacă̆ bir biçimde, dinamik dengeler yeniden kurulmaktadır. Bu dengelerin pozisyonu ${ }^{1} H$ NMR ve fluoresans spektroskopileriyle kolaylıkla izlenebilmektedir. Beklenildiği gibi, benzer kompleks yapılar oluşturmasına rağmen $\mathrm{Fe}^{I I}$ iyonu, sentezlenen tüm fonksiyonalize Bodipy ligandlarının emisyonlarını sönümlendirmektedir.
}

particularly relevant in ion-sensing applications based on earlier literature data in which chromophores were tethered by bipyridyl linkages. ${ }^{[39]}$

NMR spectroscopic study of the complexation and coordination polymer formation: Metal ion complexation results in characteristic signal changes in the ${ }^{1} \mathrm{H} N \mathrm{NR}$ spectra (Figure 1). First, the monoterpyridyl-bodipy compound $\mathbf{5}$ is

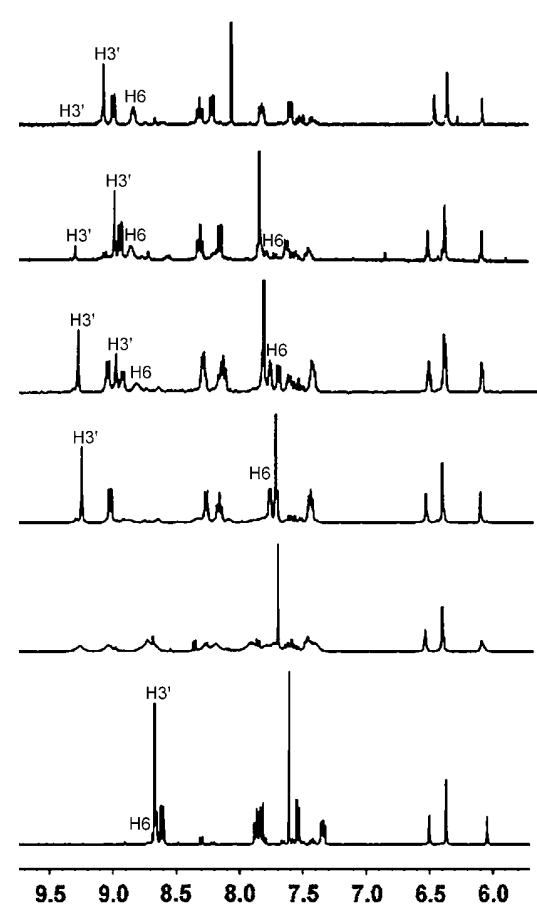

Figure 1. ${ }^{1} \mathrm{H}$ NMR spectra obtained by the titration of 5 in $60: 40 \mathrm{CDCl}_{3} /$ [D $\left.\mathrm{D}_{6}\right] \mathrm{DMSO}(13 \mathrm{~mm})$ with $\mathrm{Zn}(\mathrm{OTf})_{2} . \mathrm{Zn}^{\mathrm{II}} / \mathbf{5}$ ratio varies from bottom to top as $0: 1,0.25: 1,0.5: 1,0.75: 1,1: 1,1: 1.5$.

highly instructive. As expected, whereas the ${ }^{1} \mathrm{H}$ NMR signals corresponding to the bodipy core are not noticeably shifted upon complexation, terpyridyl signals shift to low field on $\mathrm{Zn}^{\text {II }}$ complex formation. Addition of 0.25 equivalents of $\mathrm{Zn}{ }^{\text {II }}$ to 5 results in some signal broadening together with a downfield shift. When the amount of $\mathrm{Zn}^{\text {II }}$ is increased to 0.5 equivalents, the molar ratio is just right for the $2: 1\left(\mathbf{5}_{2}-\right.$ $\mathrm{Zn}^{\mathrm{II}}$ ) complex. The most downfield sharp signal has been identified as the $\mathrm{H}^{\prime}$ ' singlet. In the 2:1 complex, it appears at $\delta=9.3 \mathrm{ppm}$. The most characteristic change is that of the

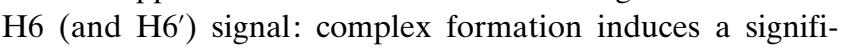
cant upfield shift because those hydrogen nuclei will be brought into the shielding zone of the pyridine rings of the other terpyridyl. As a result, in the metal-free ligand 5, the H6 nuclei resonate at $\delta=8.7 \mathrm{ppm}$, but in the $2: 1$ complex, this signal moves to $\delta=7.7 \mathrm{ppm}$. As previously demonstrated, further addition of $\mathrm{Zn}^{\text {II }}$ decreases the equilibrium concentration of the dimeric 2:1 complex in favor of the "open form" (Scheme 2). As a result, the sharp downfield $\mathrm{H}^{\prime}$ ' singlet decreases in intensity as more and more $\mathrm{Zn}^{\mathrm{II}}$ is added. At $1: 1.5$ equivalents of $\mathrm{Zn}^{\mathrm{II}}$, the signal at $\delta=9.3 \mathrm{ppm}$ practi- 


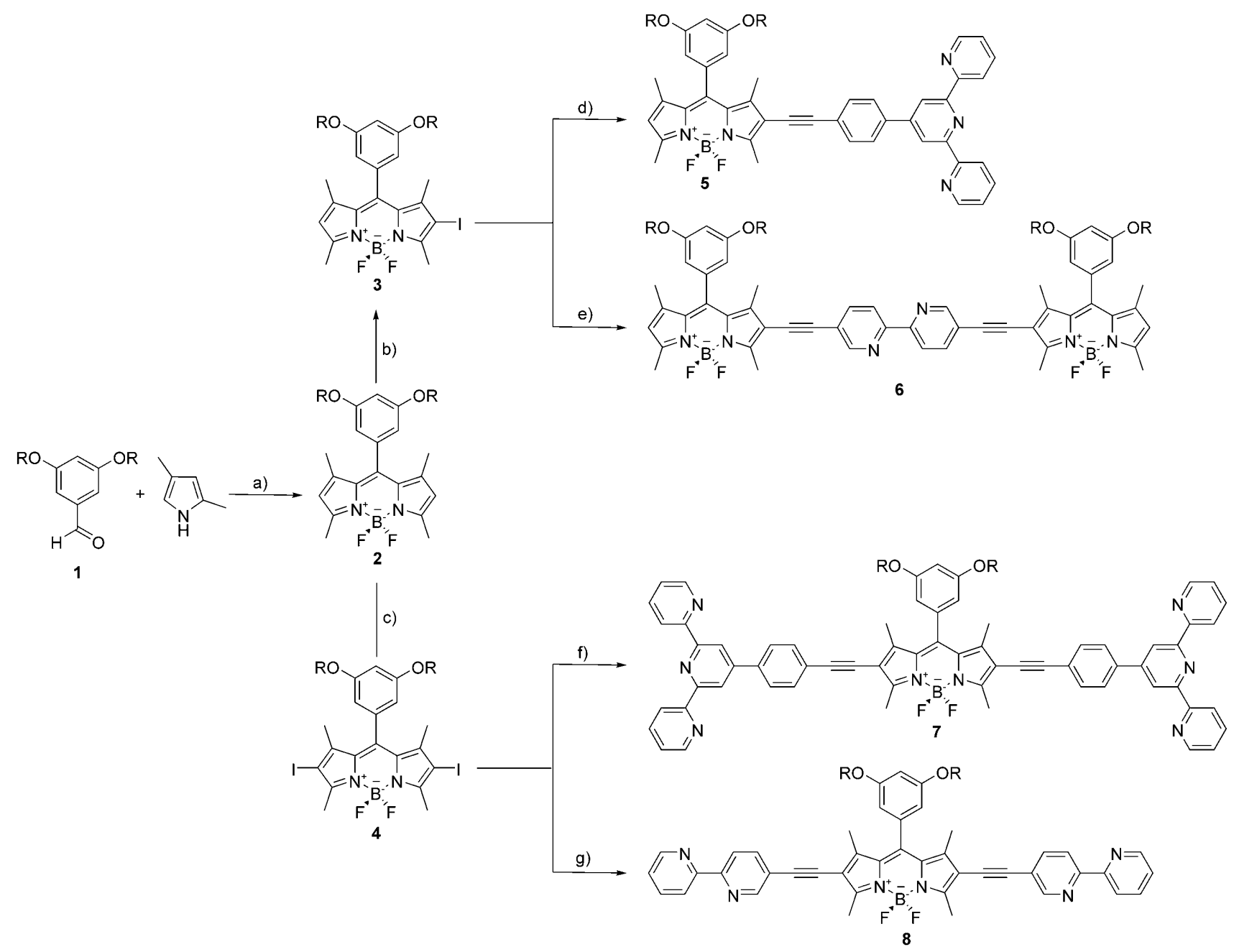

Scheme 1. a) i) 1, 2,4-dimethyl pyrrole, trifluoroacetic acid (TFA), $\mathrm{CH}_{2} \mathrm{Cl}_{2}$, RT, 1 d, ii) 2,3-dichloro-5,6-dicyano-1,4-benzoquinone (DDQ), NEt

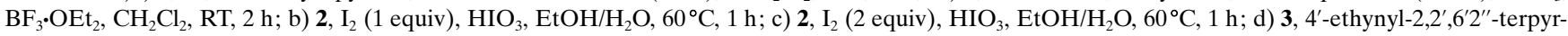
idine, $\left[\mathrm{PdCl}_{2}\left(\mathrm{PPh}_{3}\right)_{2}\right]$, CuI, THF/diisopropylamine, $50^{\circ} \mathrm{C}, 40$ min then RT, $1 \mathrm{~d}$; e) 3, 5,5'-diethynyl-2,2'-bipyridine, $\left[\mathrm{PdCl}_{2}\left(\mathrm{PPh}_{3}\right)_{2}\right], \mathrm{CuI}, \mathrm{THF} / \mathrm{diisopropyl}-$ amine, $50^{\circ} \mathrm{C}, 40$ min then RT, 1 d; f) 4, 4'-ethynyl-2,2, $6^{\prime} 2^{\prime \prime}$-terpyridine, $\left[\mathrm{PdCl}_{2}\left(\mathrm{PPh}_{3}\right)_{2}\right]$, CuI, THF/diisopropylamine $50^{\circ} \mathrm{C}, 40 \mathrm{~min}$ then RT, $1 \mathrm{~d}$; g) 5 -ethynyl-2,2'-bipyridine, $\left[\mathrm{PdCl}_{2}\left(\mathrm{PPh}_{3}\right)_{2}\right]$, CuI, THF/diisopropylamine, $50^{\circ} \mathrm{C}, 40$ min then RT, $1 \mathrm{~d}$. $\mathrm{R}=$ decyl.
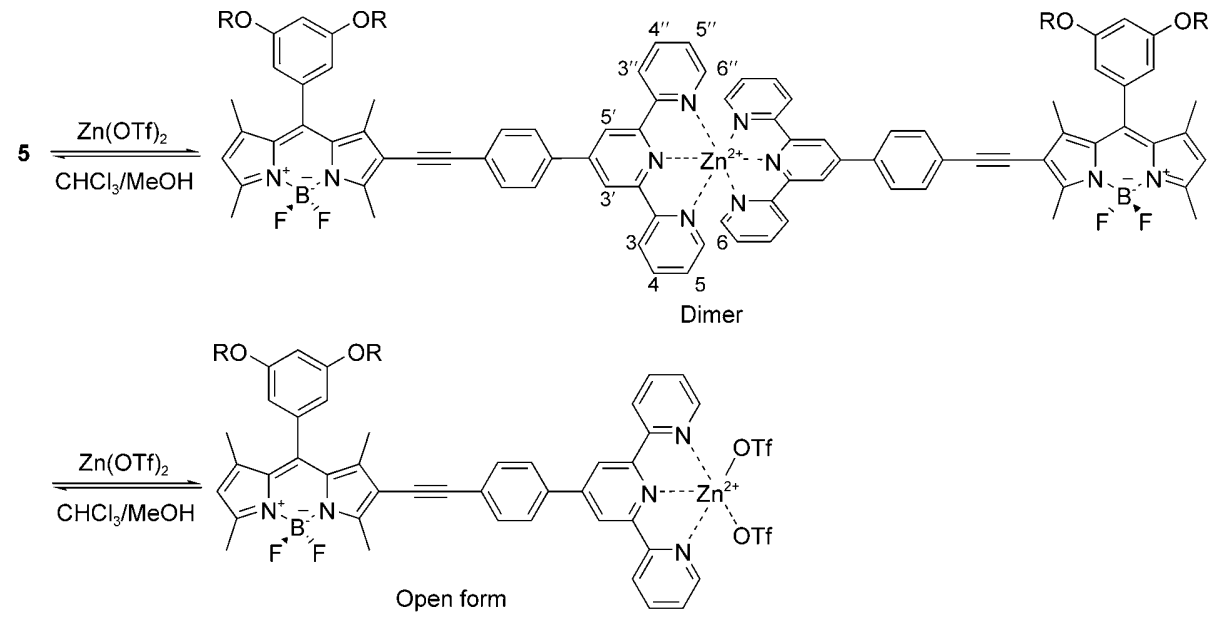

Scheme 2. Formation of dimeric and open-form structures by the addition of $\mathrm{Zn}(\mathrm{OTf})_{2}$. cally disappears and a new singlet at $\delta=9.1 \mathrm{ppm}$ becomes prominent. That particular signal corresponds to the open 1:1 $\mathrm{Zn}^{\mathrm{II}}$ complex, 5- $\mathrm{Zn}{ }^{\mathrm{II}}$. In this complex, other coordination sites of $\mathrm{Zn}^{\mathrm{II}}$ should be occupied with DMSO molecules or triflate ions. Bis(terpyridyl) compound $\mathbf{7}$ displays very clear signs of polymerization on addition of $\mathrm{Zn}^{\text {II }}$ (Figure 2). Upon addition of 0.25 equivalents of $\mathrm{Zn}^{\mathrm{II}}$, the ${ }^{1} \mathrm{H} \mathrm{NMR}$ signals become very broad. The addition of one equivalent of $\mathrm{Zn}^{\text {II }}$ should generate the largest polymer chain lengths, and this is 

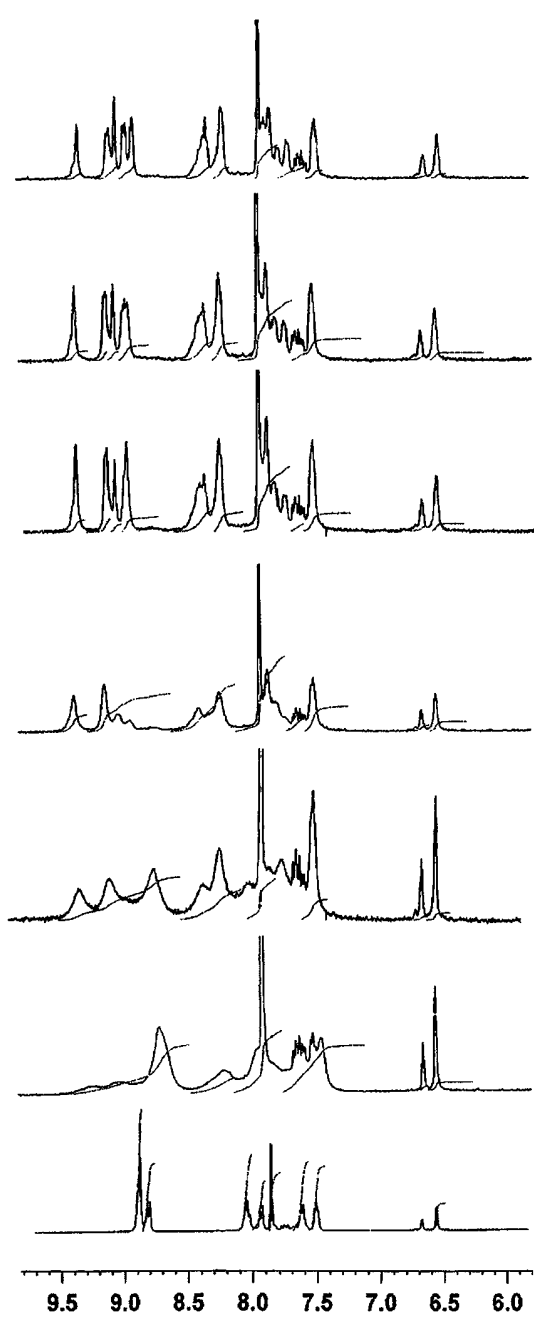

Figure $2 .{ }^{1} \mathrm{H}$ NMR spectra obtained by the titration of 7 in $60: 40 \mathrm{CDCl}_{3} /$ $\left[\mathrm{D}_{6}\right] \mathrm{DMSO}(13 \mathrm{~mm})$ with $\mathrm{Zn}(\mathrm{OTf})_{2}$. $\mathrm{Zn}^{\mathrm{II}} / 7$ ratio varies from bottom to top as $0: 1,0.25: 1,0.5: 1,0.75: 1,1: 1,2: 1,3: 1$.

clearly reflected in the broadness of the signals. As expected, the pyridine ring protons of the terpyridyl group shifted downfield. Most interestingly, addition of more than 0.5 equivalents of $\mathrm{Zn}^{\mathrm{II}}$ to ligand 7 results in sharpening of the ${ }^{1} \mathrm{H}$ NMR signals of the aromatic protons. Upon addition of one or more equivalents of $\mathrm{Zn}^{\mathrm{II}}$, the NMR spectra display a clear predominance of the 1:1 open-form complex, with very distinctively sharper monomeric aromatic hydrogen signals (Scheme 3).

Absorbance and steady-state fluorescence spectroscopic in- vestigation of the complexation and coordination polymer formation: To synthesize the building blocks, terpyridylphenyl and bipyridyl groups have been attached to the fluorophore core through ethynyl spacers; there is some conjugation and thus electronic communication between the ligand moieties and the bodipy cores. As a result, we observe spectral changes not only in peaks that correspond to $\pi-\pi^{*}$ transitions in the oligopyridine moieties, but in bodipy $\mathrm{S}_{0}-\mathrm{S}_{1}$ transitions as well. For example, in the reference compound 5, the increase in the absorption of the peak at $325 \mathrm{~nm}$ peak and the shoulder at $400 \mathrm{~nm}$ are due to terpyridyl ligand- $\mathrm{Zn}^{\mathrm{II}}$ coordinative interactions. As the inset in Figure 3 clearly shows, above 0.5 equivalents of $\mathrm{Zn}^{\mathrm{II}}$, the change in the absorption levels off very quickly, indicating a strong affinity between the ligand and the $\mathrm{Zn}^{\mathrm{II}}$ in this particular solvent system $\left(80: 20 \mathrm{CHCl}_{3} / \mathrm{MeOH}\right)$. In addition, there is a small increase of the bodipy absorption peak at $536 \mathrm{~nm}$ as the added amount of $\mathrm{Zn}^{\mathrm{II}}$ is increased (the extinction coefficient $(\varepsilon)$ changes from 95000 to $\left.104000 \mathrm{~cm}^{-1} \mathrm{M}^{-1}\right) . \mathrm{Zn}^{\mathrm{II}}$ titration of the monotopic ligand $\mathbf{5}$ shows a gradual increase in the emission intensity (Figure 4) and at saturation the intensity of the bodipy emission is nearly doubled. There is a concomitant small blueshift in the emission intensity in this peak, from 572 to $563 \mathrm{~nm}$. The equilibrium constant $\left(K_{1}\right)$ for the first binding event $\left(\mathbf{5}-\mathrm{Zn}^{\mathrm{II}}\right)$, determined by following the absorbance changes at $325 \mathrm{~nm}$, is $6.8 \times 10^{6} \mathrm{M}^{-1}$. $\mathrm{Zn}^{\mathrm{II}}$ titration of the ditopic bis(terpyridyl) bodipy ligand 7 shows similar changes. There are increases in the absorption peaks at 325 , 400 (shoulder), and $577 \mathrm{~nm}$ (bodipy $\mathrm{S}_{0}-\mathrm{S}_{1}$ transition) (Figure 5). As expected, the absorption changes at $325 \mathrm{~nm}$ (Figure 5, inset) level off only after one equivalent of $\mathrm{Zn}^{\text {II }}$ ions were added (1:1). In the fluorescence spectrum (Figure 6$)$, there is a minor increase $(+30 \%)$ in the intensity with just a few nanometers of blueshift in the peak position (from 608 to $602 \mathrm{~nm}$ ). As expected, the bipyridyl- $\mathrm{Zn}^{\mathrm{II}}$ interaction is weaker, and coordination stoichiometry and spatial arrangement of the bodipy chromophores should be differ-
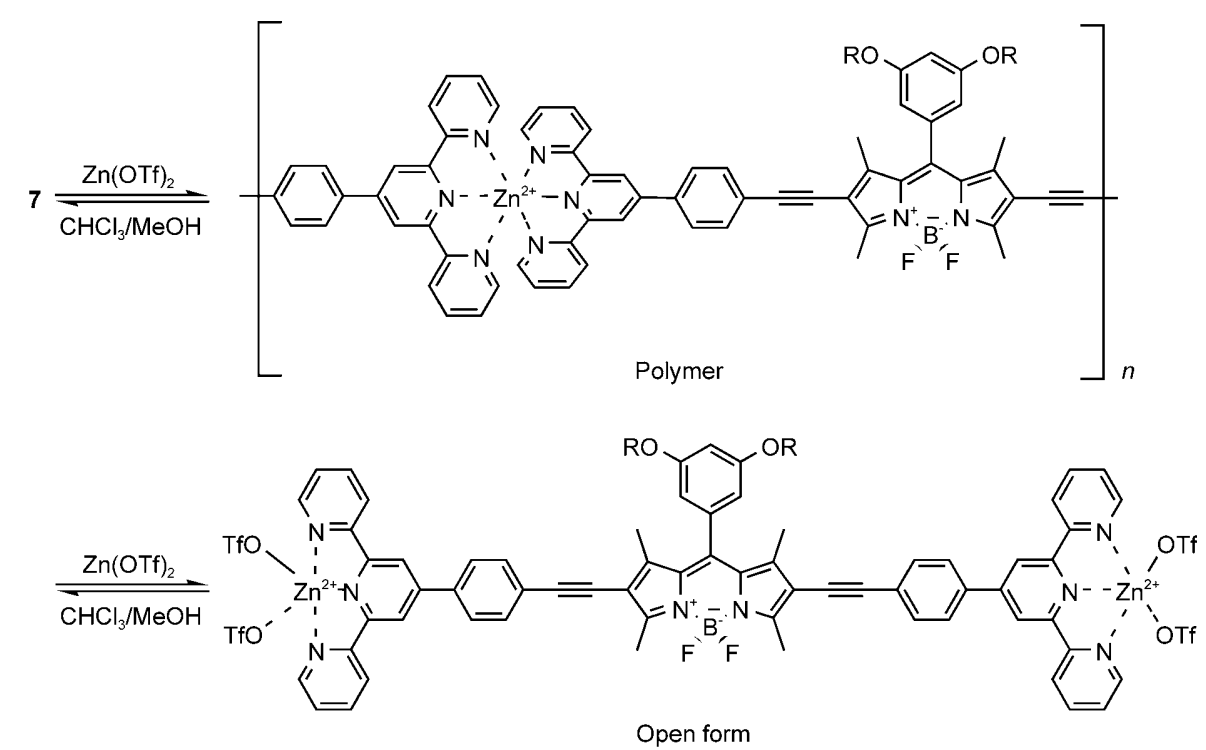

Scheme 3. Formation of polymeric and open-form structures by the addition of $\mathrm{Zn}(\mathrm{OTf})_{2}$. 


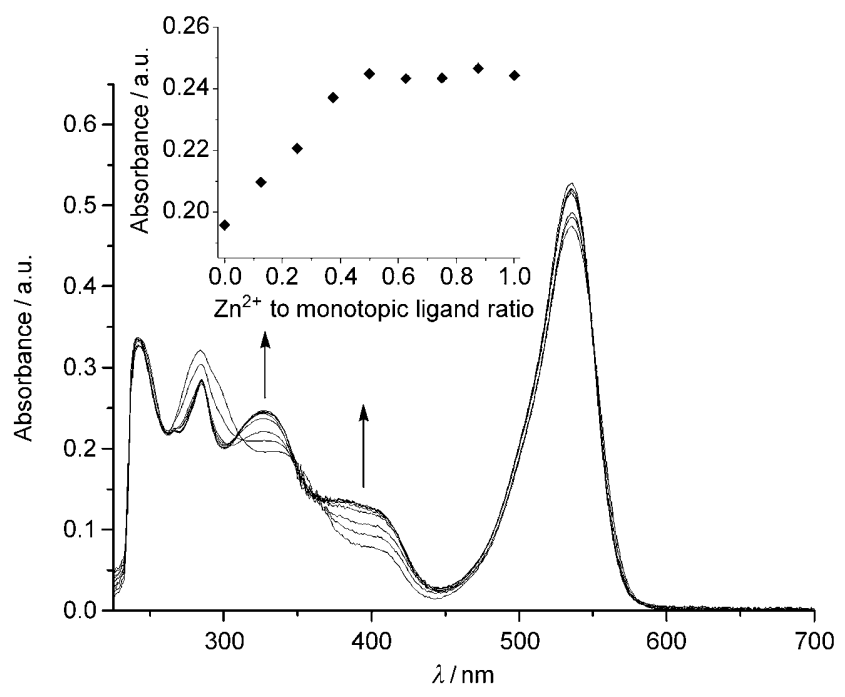

Figure 3. UV/Vis spectra obtained by the titration of 5 in $80: 20 \mathrm{CHCl}_{3} /$ $\mathrm{MeOH}\left(5.0 \times 10^{-6} \mathrm{M}\right)$ with $\mathrm{Zn}(\mathrm{OTf})_{2}$. The inset shows the absorption coefficient at $325 \mathrm{~nm}$ as a function of the $\mathrm{Zn}^{\mathrm{II}} / \mathbf{5}$ ratio.

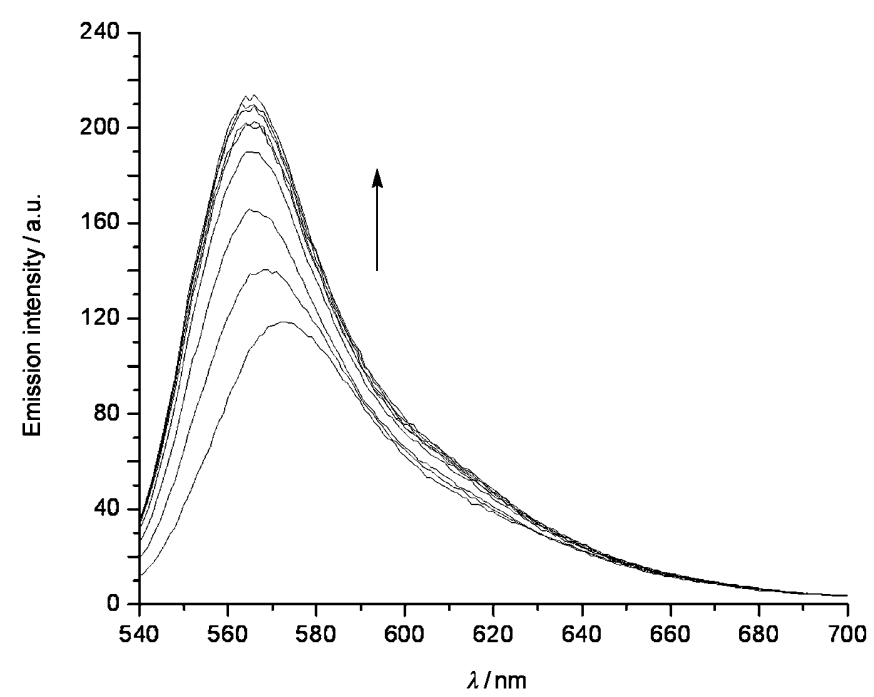

Figure 4. Fluorescence spectra obtained by the titration of $\mathbf{5}$ in $80: 20$ $\mathrm{CHCl}_{3} / \mathrm{MeOH}\left(5.0 \times 10^{-6} \mathrm{M}\right)$ with $\mathrm{Zn}(\mathrm{OTf})_{2}$.

ent from the terpyridine derivatives. On saturation with $\mathrm{Zn}^{\mathrm{II}}$, the absorption spectra of compound 6 (Figure 7) display minor changes at 380 (decrease) and $541 \mathrm{~nm}$ (increase), the emission peak intensity increases $(+44 \%$, Figure 8$)$, and the peak shifts blue (from 567 to $558 \mathrm{~nm}$ ). The $K_{1}$ value for the first binding event $\left(6-\mathrm{Zn}^{\mathrm{II}}\right)$, determined by following the emission changes at the peak wavelength $(558 \mathrm{~nm})$, is $2.2 \times$ $10^{5} \mathrm{M}^{-1}$. In contrast, bis(bipyridylbodipy) 8 shows a somewhat complicated response in absorption spectra during titration (Figure 9). Whereas the peak at $400 \mathrm{~nm}$ behaves normally (an increase with an expected saturation behavior), the bodipy peak shows an increase: growth of a shoulder at $530 \mathrm{~nm}$ and then disappearance of the shoulder with a final increase at $562 \mathrm{~nm}$. We speculate that the growth of a shoulder is suggestive of interchromophoric stacking with

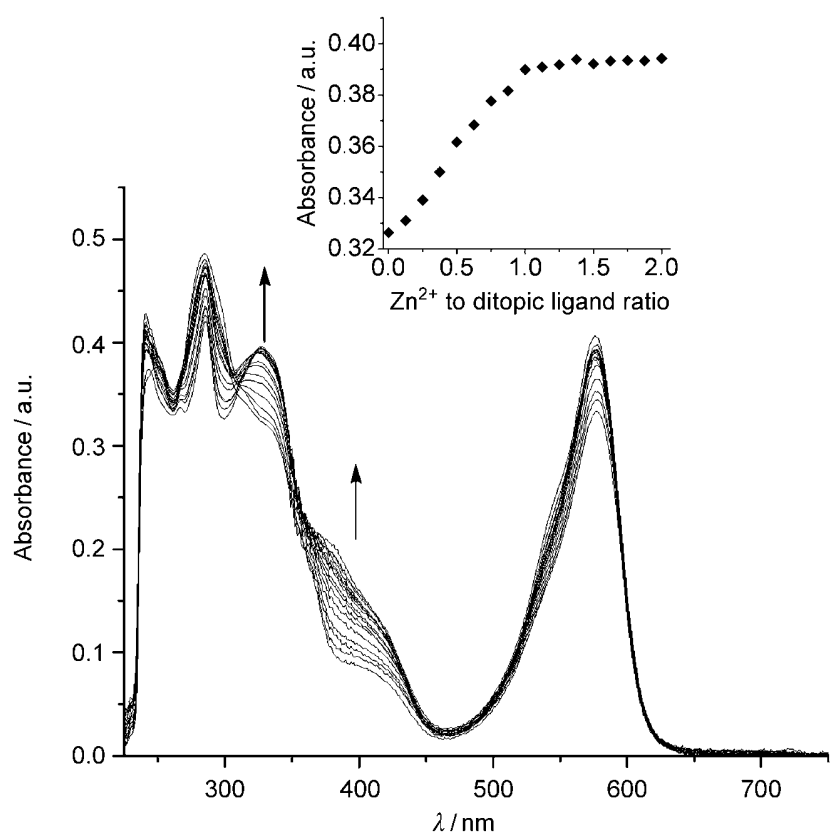

Figure 5. UV/Vis spectra obtained by the titration of 7 in $80: 20 \mathrm{CHCl}_{3} /$ $\mathrm{MeOH}\left(5.0 \times 10^{-6} \mathrm{M}\right)$ with $\mathrm{Zn}(\mathrm{OTf})_{2}$. The inset shows the absorption coefficient at $325 \mathrm{~nm}$ as a function of $\mathrm{Zn}^{\mathrm{II}} / 7$ ratio.

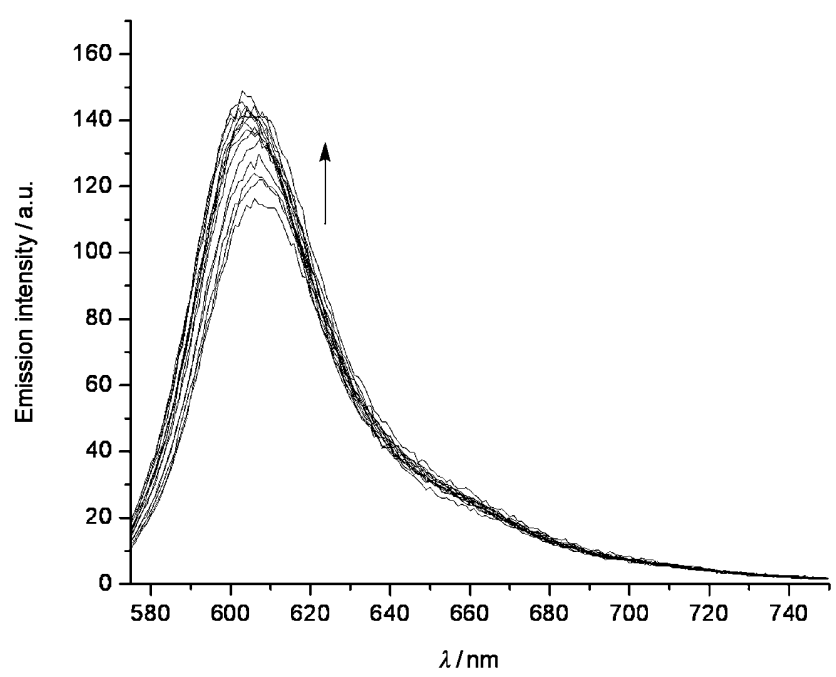

Figure 6. Fluorescence spectra obtained by the titration of 7 in $80: 20$ $\mathrm{CHCl}_{3} / \mathrm{MeOH}\left(5.0 \times 10^{-6} \mathrm{M}\right)$ with $\mathrm{Zn}(\mathrm{OTf})_{2}$.

lower $\mathrm{Zn}^{\mathrm{II}}$ to ligand ratios, in which two bodipys might be brought together in an octahedral arrangement. Increasing $\mathrm{Zn}^{\mathrm{II}}$ concentration would of course favor an open form resembling that of the terpyridyl derivatives. The $K_{1}$ value for the first binding event $\left(\mathbf{8}-\mathrm{Zn}^{\mathrm{II}}\right)$, determined by following the emission changes at the peak wavelength $(588 \mathrm{~nm})$, is $1.7 \times$ $10^{6} \mathrm{M}^{-1}$. Emission spectra (Figure 10) are supportive of this speculation; at lower $\mathrm{Zn}^{\text {II }}$ concentrations, binding causes more spectral blueshift rather than intensity change, but at larger proportions of $\mathrm{Zn}^{\text {II }}$, bodipy groups are removed from each other with the formation of open-form structures, de- 


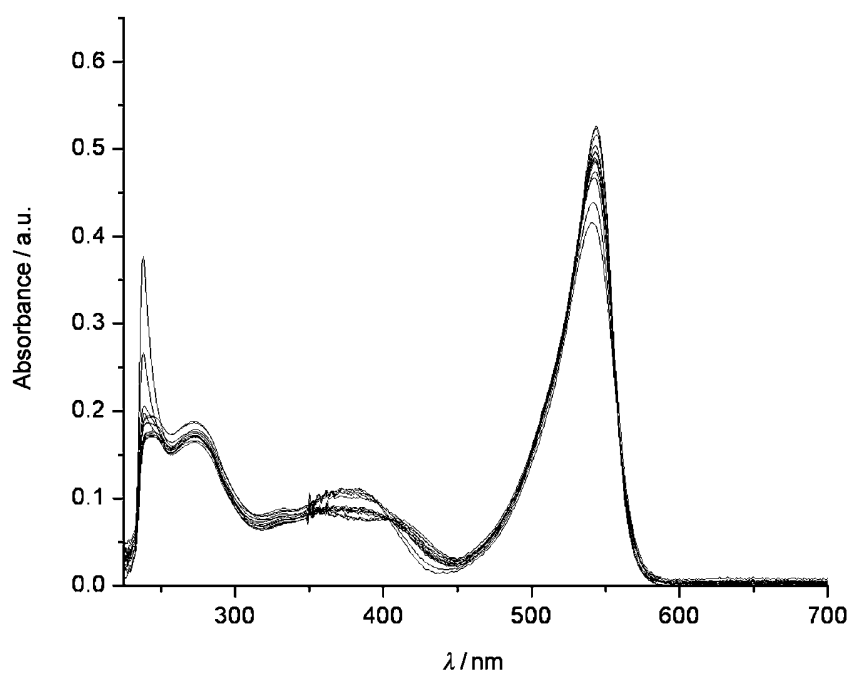

Figure 7. UV/Vis spectra obtained by the titration of $\mathbf{6}$ in $80: 20 \mathrm{CHCl}_{3} /$ $\mathrm{MeOH}\left(5.0 \times 10^{-6} \mathrm{M}\right)$ with $\mathrm{Zn}(\mathrm{OTf})_{2}$.

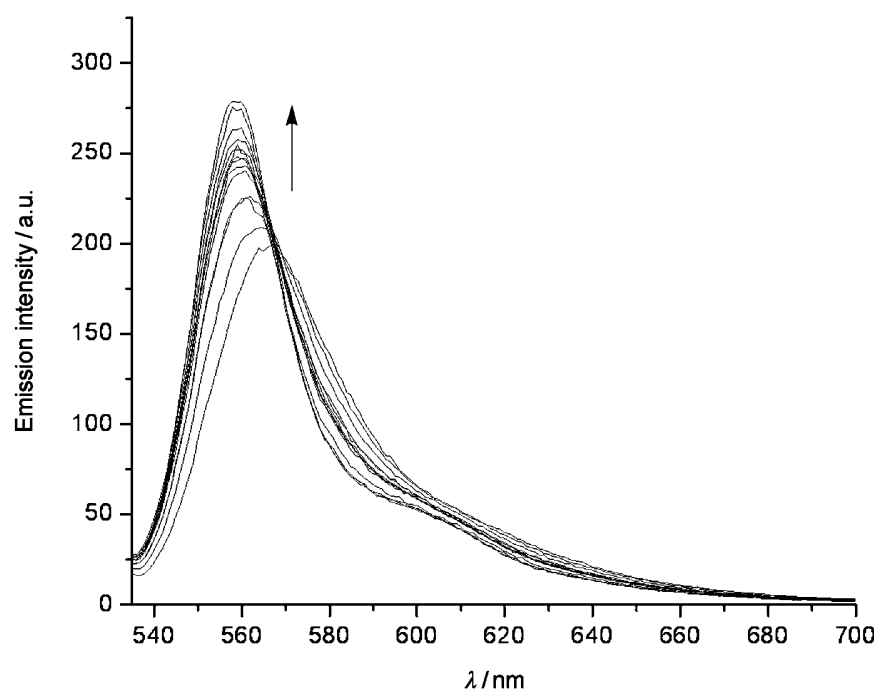

Figure 8. Fluorescence spectra obtained by the titration of 6 in 80:20 $\mathrm{CHCl}_{3} / \mathrm{MeOH}\left(5.0 \times 10^{-6} \mathrm{M}\right)$ with $\mathrm{Zn}(\mathrm{OTf})_{2}$.

creasing the effects of self-quenching of the bodipy fluorophores. The complex formation with $\mathrm{Fe}^{\mathrm{II}}$ quenches the fluorescence emission in all cases (see the Supporting Information), which is not surprising considering that $\mathrm{Fe}^{\mathrm{II}}$ is an open-shell cation with available oxidation states. Spectroscopic data for the free ligands and their $\mathrm{Zn}^{\mathrm{II}}$ complexes are presented in Table 1.

Mass spectrometric studies of the metal complexes: Mass spectrometry of the polymeric species does not yield large molecular weight peaks, in accordance with previous reports on metallosupramolecular polymers. ${ }^{[10]}$ However, at any ratio near 1:2 equivalency between the $\mathrm{Zn}^{\mathrm{II}}$ ions and $\mathbf{5}$, four easily identifiable peaks are observed by using MALDITOF spectrometry: $\mathbf{5}_{2}-\mathrm{Zn}$ at $1999.4 \mathrm{amu}, \mathbf{5}-\mathrm{Zn}(\mathrm{OTf})_{2}$ at $1918.8 \mathrm{amu}, \mathbf{5}-\mathrm{Zn}(\mathrm{OTf})_{2}$ at $1183.7 \mathrm{amu}$, and $\mathbf{5}$ at $968.7 \mathrm{amu}$.

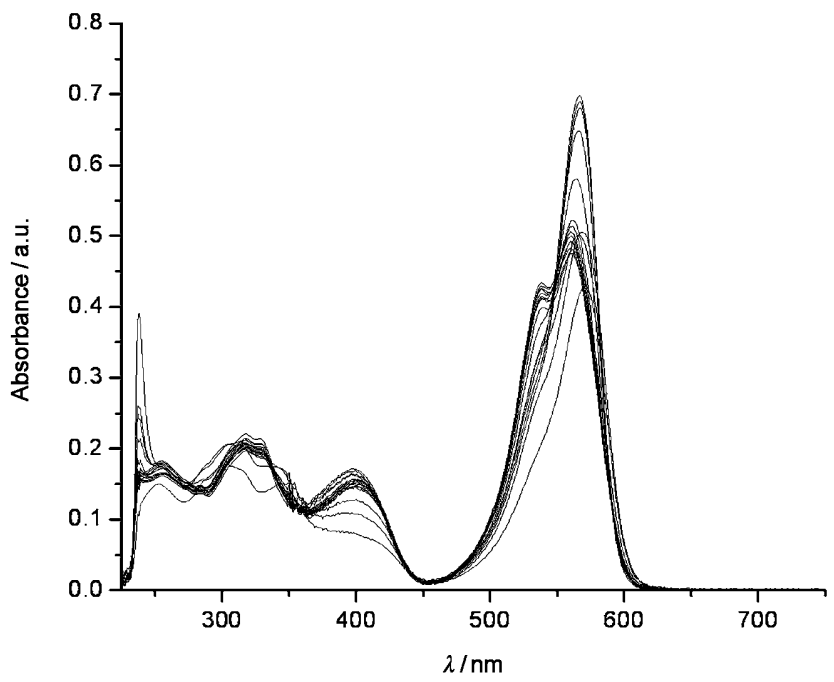

Figure 9. UV/Vis spectra obtained by the titration of 8 in $80: 20 \mathrm{CHCl}_{3}$ / $\mathrm{MeOH}\left(5.0 \times 10^{-6} \mathrm{M}\right)$ with $\mathrm{Zn}(\mathrm{OTf})_{2}$.

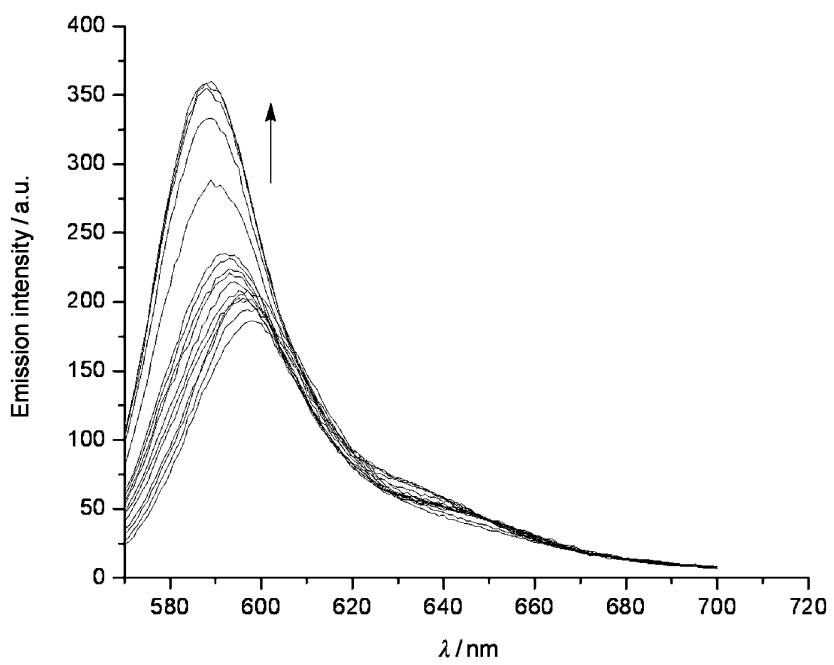

Figure 10. Fluorescence spectra obtained by the titration of $\mathbf{8}$ in 80:20 $\mathrm{CHCl}_{3} / \mathrm{MeOH}\left(5.0 \times 10^{-6} \mathrm{M}\right)$ with $\mathrm{Zn}(\mathrm{OTf})_{2}$.

Table 1. Spectroscopic ${ }^{[\mathrm{a}]}$ data for free and $\mathrm{Zn}^{\mathrm{II}}$-complexed ligands.

\begin{tabular}{lllllllll}
\hline & $\begin{array}{l}\lambda_{\mathrm{abs}} \\
{[\mathrm{nm}]}\end{array}$ & $\begin{array}{c}\lambda_{\mathrm{abs}}[\mathrm{b}] \\
{[\mathrm{nm}]}\end{array}$ & $\begin{array}{l}\lambda_{\mathrm{f}} \\
{[\mathrm{nm}]}\end{array}$ & $\begin{array}{l}\lambda_{\mathrm{f}}^{\mathrm{b}]} \\
{[\mathrm{nm}]}\end{array}$ & $\begin{array}{l}\varepsilon_{\text {max }} \\
{\left[\mathrm{M}^{-1} \mathrm{~cm}^{-1}\right]}\end{array}$ & $\begin{array}{l}\varepsilon_{\text {max }}[\mathrm{b}] \\
{\left[\mathrm{M}^{-1} \mathrm{~cm}^{-1}\right]}\end{array}$ & $\phi_{\mathrm{f}}$ & $\phi_{\mathrm{f}}^{[\mathrm{b}]}$ \\
\hline $\mathbf{5}$ & 536 & 535 & 572 & 563 & 95000 & 104000 & $0.27^{[\mathrm{c}]}$ & $0.29^{[\mathrm{c}]}$ \\
$\mathbf{6}$ & 541 & 543 & 567 & 558 & 67000 & 81000 & $0.29^{[\mathrm{c}]}$ & $0.32^{[\mathrm{c}]}$ \\
$\mathbf{7}$ & 577 & 576 & 608 & 602 & 83200 & 98000 & $0.47^{[\mathrm{d}]}$ & $0.49^{[\mathrm{d}]}$ \\
$\mathbf{8}$ & 571 & 567 & 598 & 588 & 86000 & 136000 & $0.53^{[\mathrm{d}]}$ & $0.67^{[\mathrm{d}]}$
\end{tabular}

[a] Determined in 80:20 $\mathrm{CHCl}_{3} / \mathrm{MeOH}$ solution. [b] Recorded in the presence of $\mathrm{Zn}^{\mathrm{II}}$. [c] Rhodamine $6 \mathrm{G}$ in water $\left(\phi_{\mathrm{f}}=0.95\right)$ was used as reference. [d] Sulforhodamine 101 hydrate in ethanol $\left(\phi_{\mathrm{f}}=0.90\right)$ was used as reference.

Both the open form with the triflate counterions, and the dimeric complex shown in Scheme 2 appear on the mass spectrum (see the Supporting Information). 


\section{Conclusion}

Through the use of Sonogashira couplings, four functional building blocks carrying bodipy fluorophores were synthesized. Ter- and bipyridyl ligands have been repeatedly shown to be very useful in the construction of supramolecular structures. Terpyridyl is a strong enough ligand for $\mathrm{Zn}^{\mathrm{II}}$ ions, and the addition of zinc triflate forms a fluorescent coordination polymer. This polymerization process can be easily followed by the observation of fluorescence characteristics. Ditopic bis(terpyridyl) bodipy ligand 7 shows clear evidence of polymerization when 0.5 equivalents of $\mathrm{Zn}^{\mathrm{II}}$ ions were added. The addition of $\mathrm{Zn}^{\mathrm{II}}$ changes the dynamic equilibrium concentration of the polymer, and the ${ }^{1} \mathrm{H}$ NMR signals become more sharp as more $\mathrm{Zn}^{\text {II }}$ ions are added, which indicates a monomeric complex (open form). With their lower affinities, bipyridyl derivatives can also be useful as fluorescent chemosensors when considering that intracellular $\mathrm{Zn}^{\mathrm{II}}$ concentrations can vary by six orders of magnitude. A fluorescent coordination polymer may find utility in electrochromic devices or in other device applications in which reversible changes between states of different physical properties is an asset.

\section{Experimental Section}

General: ${ }^{1} \mathrm{H}$ and ${ }^{13} \mathrm{C}$ NMR spectra were recorded on a Bruker DPX-400 spectrometer (operating at $400 \mathrm{MHz}$ for ${ }^{1} \mathrm{HNMR}$ and $100 \mathrm{MHz}$ for ${ }^{13} \mathrm{C}$ NMR) in $\mathrm{CDCl}_{3}$ and $\left[\mathrm{D}_{6}\right] \mathrm{DMSO}$ with tetramethylsilane as an internal standard. All spectra were recorded at $25^{\circ} \mathrm{C}$ and coupling constants $(J$ values) are given in $\mathrm{Hz}$. Chemical shifts are given in parts per million $(\mathrm{ppm})$. Absorption spectra were obtained by using a Varian Cary-100 spectrophotometer. Fluorescence measurements were conducted on a Varian Eclipse spectrofluorimeter. Mass spectra were recorded at the Ohio State University Mass Spectrometry and Proteomics Facility, Ohio, USA. Reactions were monitored by TLC using Merck TLC Silica gel 60 $\mathrm{F}_{254}$ and Merck Aluminium Oxide $60 \mathrm{~F}_{254}$. Silica gel column chromatography was performed over Merck Silica gel 60 (particle size: 0.040$0.063 \mathrm{~mm}, 230-400$ mesh ASTM). Aluminium oxide column chromatography was performed using Merck Aluminium Oxide 90 active neutral. 4'-(4-Ethynylphenyl)-2,2',6',2'-terpyridine, 5,5'-diethynyl-2,2'-bipyridine, and 5-ethynyl-2,2'-bipyridine were synthesized according to literature procedures. ${ }^{[2,43]}$ Anhydrous tetrahydrofuran was obtained by heating at reflux over sodium/benzophenone prior to use. All other reagents and solvents were purchased from Aldrich and used without further purification.

UV/Vis and fluorescence titration experiments: UV/Vis and fluorescence titrations were conducted at $25^{\circ} \mathrm{C}$ as constant host titrations. Aliquots of $\mathrm{Zn}(\mathrm{OTf})_{2}\left(0.025 \mathrm{~mm}\right.$ in $\left.80: 20 \mathrm{CHCl}_{3} / \mathrm{MeOH}\right)$ and solvent mixture $(80: 20$ $\left.\mathrm{CHCl}_{3} / \mathrm{MeOH}\right)$ were added to a solution of $5,6,7$, or $8(0.025 \mathrm{~mm}$ in $80: 20 \mathrm{CHCl}_{3} / \mathrm{MeOH}$ ) to obtain the desired metal to ligand ratio. After each addition, UV/Vis absorption and fluorescence spectra were recorded. ( $\lambda_{\mathrm{ex}}=535 \mathrm{~nm}$ for $\mathbf{5}$ and $\mathbf{6}$, and $570 \mathrm{~nm}$ for $\mathbf{7}$ and $\left.\mathbf{8}\right)$.

${ }^{1}$ H NMR titration experiments: Aliquots of $\mathrm{Zn}(\mathrm{OTf})_{2}(13 \mathrm{~mm}$ and $10 \mathrm{~mm}$ in 60:40 $\left.\mathrm{CDCl}_{3} /\left[\mathrm{D}_{6}\right] \mathrm{DMSO}\right)$, respectively) and solvent mixture $(60: 40$ $\left.\mathrm{CDCl}_{3} /\left[\mathrm{D}_{6}\right] \mathrm{DMSO}\right)$ were added to a solution of $5(13 \mathrm{~mm}$ in $60: 40$ $\left.\mathrm{CDCl}_{3} /\left[\mathrm{D}_{6}\right] \mathrm{DMSO}\right)$ or $7\left(10 \mathrm{~mm}\right.$ in $\left.60: 40 \mathrm{CDCl}_{3} /\left[\mathrm{D}_{6}\right] \mathrm{DMSO}\right)$ to obtain the desired metal-to-ligand ratio, and after each addition, ${ }^{1} \mathrm{H}$ NMR spectra were recorded at $25^{\circ} \mathrm{C}$.

3,5-Bis(decyloxy)benzaldehyde (1): 3,5-Bis(decyloxy)benzyl alcohol $(21.40 \mathrm{mmol}, 9.00 \mathrm{~g})$ and PCC $(53.49 \mathrm{mmol}, 11.53 \mathrm{~g})$ were added to a
$500 \mathrm{~mL}$ round-bottomed flask containing $\mathrm{CH}_{2} \mathrm{Cl}_{2}(250 \mathrm{~mL})$, and the reaction mixture was stirred for $3 \mathrm{~h}$ at room temperature. The reaction mixture was then washed with water and the organic phase was evaporated at reduced pressure. Silica gel column chromatography using $\mathrm{CHCl}_{3}$ as the eluant gave $\mathbf{1}$ as a waxy solid $(8.1 \mathrm{~g}, 90 \%) .{ }^{1} \mathrm{H} \mathrm{NMR}(400 \mathrm{MHz}$, $\left.\mathrm{CDCl}_{3}\right): \delta=9.80(1 \mathrm{H}, \mathrm{s} ; \mathrm{CHO}), 6.93(2 \mathrm{H}, \mathrm{s} ; \mathrm{ArH}), 6.60(1 \mathrm{H}, \mathrm{s} ; \mathrm{ArH})$ $3.92\left(4 \mathrm{H}, \mathrm{t}, J=6.49 \mathrm{~Hz} ; \mathrm{OCH}_{2}\right), 1.75-1.65\left(4 \mathrm{H}, \mathrm{m} ; \mathrm{CH}_{2}\right), 1.41-1.32(4 \mathrm{H}$, $\left.\mathrm{m} ; \mathrm{CH}_{2}\right), 1.20\left(24 \mathrm{H}, \mathrm{s} ; \mathrm{CH}_{2}\right), 0.80 \mathrm{ppm}\left(6 \mathrm{H}, \mathrm{t}, J=6.59 \mathrm{~Hz} ; \mathrm{CH}_{3}\right)$; ${ }^{13} \mathrm{C} \mathrm{NMR}\left(100 \mathrm{MHz}, \mathrm{CDCl}_{3}\right): \delta=192.0,160.8,138.4,108.1,107.1,68.5$, 31.9, 29.6, 29.5, 29.3, 29.1, 26.0, 22.7, $14.1 \mathrm{ppm}$.

4,4-Difluoro-8-[3',5'-bis(decyloxy)phenyl]-1,3,5,7-tetramethyl-4-bora-

3a,4a-diaza-s-indacene (2): 2,4-Dimethyl pyrrole (15.8 mmol, $1.50 \mathrm{~g})$ and 1 ( $7.17 \mathrm{mmol}, 3 \mathrm{~g})$ were added to a $1 \mathrm{~L}$ round-bottomed flask containing argon-degassed $\mathrm{CH}_{2} \mathrm{Cl}_{2}(400 \mathrm{~mL})$. One drop of TFA was added and the solution was stirred under nitrogen at room temperature for $1 \mathrm{~d}$. After addition of a solution of DDQ (7.17 mmol, $1.628 \mathrm{~g})$ in $\mathrm{CH}_{2} \mathrm{Cl}_{2}(100 \mathrm{~mL})$, stirring was continued for $30 \mathrm{~min} . \mathrm{Et}_{3} \mathrm{~N}(6 \mathrm{~mL})$ and $\mathrm{BF}_{3} \cdot \mathrm{OEt}_{2}(3 \mathrm{~mL})$ were successively added and after $30 \mathrm{~min}$, the reaction mixture was washed three times with water and dried over anhydrous $\mathrm{Na}_{2} \mathrm{SO}_{4}$. The solvent was evaporated and the residue was purified by silica gel column chromatography using 2:1 $\mathrm{CHCl}_{3}$ /hexane as the eluant to give $\mathbf{2}$ as a red waxy solid (1.381 g, 30\%). ${ }^{1} \mathrm{H}$ NMR $\left(400 \mathrm{MHz}, \mathrm{CDCl}_{3}\right): \delta=6.45(1 \mathrm{H}$, s; ArH), 6.35 (2H, s; ArH), 5.90 (2H, s; H2, H6), $3.85(4 \mathrm{H}, \mathrm{t}, J=6.56 \mathrm{~Hz}$; $\left.\mathrm{OCH}_{2}\right), 2.47\left(6 \mathrm{H}, \mathrm{s} ; \mathrm{CH}_{3}\right), 1.72-1.62\left(4 \mathrm{H}, \mathrm{m} ; \mathrm{CH}_{2}\right), 1.49\left(6 \mathrm{H}, \mathrm{s} ; \mathrm{CH}_{3}\right)$, $1.40-1.30\left(4 \mathrm{H}, \mathrm{m} ; \mathrm{CH}_{2}\right), 1.20\left(24 \mathrm{H}, \mathrm{s} ; \mathrm{CH}_{2}\right), 0.80 \mathrm{ppm}(6 \mathrm{H}, \mathrm{t}, J=$ $\left.6.53 \mathrm{~Hz} ; \mathrm{CH}_{3}\right) ;{ }^{13} \mathrm{C} \mathrm{NMR}\left(100 \mathrm{MHz}, \mathrm{CDCl}_{3}\right): \delta=161.2,155.4,143.2$, 136.4, 131.2, 121.0, 106.4, 102.3, 68.4, 31.9, 29.6, 29.5, 29.3, 29.2, 26.0, 22.7, 14.6, 14.2, 14.0 ppm; HRMS (TOF-ESI): $m / z$ calcd for $\mathrm{C}_{39} \mathrm{H}_{59} \mathrm{BF}_{2} \mathrm{~N}_{2} \mathrm{O}_{2} \mathrm{Na}$ : $658.4572[M+\mathrm{Na}]^{+}$; found: $658.4542[M+\mathrm{Na}]^{+}$.

\section{4,4-Difluoro-8-[3',5'-bis(decyloxy)phenyl]-2-iodo-1,3,5,7-tetramethyl-4-} bora-3a,4a-diaza-s-indacene (3): Compound 2 (1.91 mmol, $1.21 \mathrm{~g})$ and iodine $(1.52 \mathrm{mmol}, 0.387 \mathrm{~g})$ were added to a $500 \mathrm{~mL}$ round-bottomed flask and to this solution iodic acid $(1.52 \mathrm{mmol}, 0.268 \mathrm{~g})$ dissolved in water $(2 \mathrm{~mL})$ was added. The reaction mixture was stirred at $60^{\circ} \mathrm{C}$ and was monitored by TLC $\left(1: 1 \mathrm{CHCl}_{3} /\right.$ hexanes). When TLC indicated that all the starting material had been consumed, the reaction was quenched by the addition of a saturated aqueous solution of $\mathrm{Na}_{2} \mathrm{~S}_{2} \mathrm{O}_{3}(100 \mathrm{~mL})$ and the product was extracted into $\mathrm{CHCl}_{3}$. The solvent was evaporated and the residue was purified by silica gel column chromatography using 1:1 $\mathrm{CHCl}_{3} /$ hexane as the eluant to give 3 as a red waxy solid $(0.98 \mathrm{~g}, 67 \%)$. ${ }^{1} \mathrm{H}$ NMR $\left(400 \mathrm{MHz}, \mathrm{CDCl}_{3}\right): \delta=6.48(1 \mathrm{H}, \mathrm{s} ; \operatorname{ArH}), 6.32(2 \mathrm{H}, \mathrm{d}, J=$ $1.90 \mathrm{~Hz} ; \mathrm{ArH}), 5.97(1 \mathrm{H}, \mathrm{s} ; \mathrm{H} 2), 3.85\left(4 \mathrm{H}, \mathrm{t}, J=6.60 \mathrm{~Hz} ; \mathrm{OCH}_{2}\right), 2.55$ $\left(3 \mathrm{H}, \mathrm{s} ; \mathrm{CH}_{3}\right), 2.49\left(3 \mathrm{H}, \mathrm{s} ; \mathrm{CH}_{3}\right), 1.72-1.62\left(4 \mathrm{H}, \mathrm{m} ; \mathrm{CH}_{2}\right), 1.49(6 \mathrm{H}, \mathrm{s}$; $\left.\mathrm{CH}_{3}\right), 1.40-1.30\left(4 \mathrm{H}, \mathrm{m} ; \mathrm{CH}_{2}\right), 1.20\left(24 \mathrm{H}, \mathrm{s} ; \mathrm{CH}_{2}\right), 0.8 \mathrm{ppm}(6 \mathrm{H}, \mathrm{t}, J=$ 6.60; $\left.\mathrm{CH}_{3}\right) ;{ }^{13} \mathrm{C} \mathrm{NMR}\left(100 \mathrm{MHz}, \mathrm{CDCl}_{3}\right): \delta=161.3,157.7,154.4,145.1$, $143.2,141.5,136.2,131.6,130.7,122.1,106.2,102.5,84.1,68.4,38.2,33.8$, $32.9,31.9,31.3,29.7,29.6,29.5,29.4,29.3,29.2,28.8,28.2,26.1,26.0,25.8$, 22.7, 16.5, 15.7, 14.7, 14.5, $14.1 \mathrm{ppm}$; HRMS (TOF-ESI): $\mathrm{m} / \mathrm{z}$ calcd for $\mathrm{C}_{39} \mathrm{H}_{58} \mathrm{BF}_{2} \mathrm{IN}_{2} \mathrm{O}_{2} \mathrm{Na}: 784.3538[M+\mathrm{Na}]^{+}$; found: $784.3513[M+\mathrm{Na}]^{+}$.

4,4-Difluoro-8-[3,5-bis(decyloxy)phenyl]-2,6-diiodo-1,3,5,7-tetramethyl-4bora-3a,4a-diaza-s-indacene (4): Compound $2(2.47 \mathrm{mmol}, 1.57 \mathrm{~g})$ and iodine $(6.18 \mathrm{mmol}, 1.57 \mathrm{~g})$ were added to a $500 \mathrm{~mL}$ round-bottomed flask. A solution of iodic acid $(4.93 \mathrm{mmol}, 0.87 \mathrm{~g})$ in water $(2 \mathrm{~mL})$ was added and the reaction mixture was stirred at $60^{\circ} \mathrm{C}$ and monitored by TLC (1:1 $\mathrm{CHCl}_{3} /$ hexane). When all the starting material had been consumed, the reaction was quenched by the addition of a saturated aqueous solution of $\mathrm{Na}_{2} \mathrm{~S}_{2} \mathrm{O}_{3}(100 \mathrm{~mL})$ and the product was extracted into $\mathrm{CHCl}_{3}$. The solvent was evaporated and the residue was purified by silica gel column chromatography using $1: 1 \mathrm{CHCl}_{3} /$ hexane as the eluant to give 4 as a red waxy solid $(2.09 \mathrm{~g}, 95 \%) .{ }^{1} \mathrm{H} \mathrm{NMR}\left(400 \mathrm{MHz}, \mathrm{CDCl}_{3}\right): \delta=6.49$ $(1 \mathrm{H}, \mathrm{s} ; \mathrm{ArH}), 6.28(2 \mathrm{H}, \mathrm{s} ; \mathrm{ArH}), 3.85\left(4 \mathrm{H}, \mathrm{t}, J=6.45 \mathrm{~Hz} ; \mathrm{OCH}_{2}\right), 2.55$ $\left(6 \mathrm{H}, \mathrm{s} ; \mathrm{CH}_{3}\right), 1.73-1.63\left(4 \mathrm{H}, \mathrm{m} ; \mathrm{CH}_{2}\right), 1.49\left(6 \mathrm{H}, \mathrm{s} ; \mathrm{CH}_{3}\right), 1.40-1.30(4 \mathrm{H}$, m; $\left.\mathrm{CH}_{2}\right), 1.20\left(24 \mathrm{H}, \mathrm{s} ; \mathrm{CH}_{2}\right), 0.80 \mathrm{ppm}\left(6 \mathrm{H}, \mathrm{t}, J=6.32 \mathrm{~Hz} ; \mathrm{CH}_{3}\right)$; ${ }^{13} \mathrm{C}$ NMR $\left(100 \mathrm{MHz}, \mathrm{CDCl}_{3}\right): \delta=161.4,156.7,145.4,141.4,136.1,131.0$, $106.1,102.7,85.5,68.5,31.9,29.6,29.5,29.4,29.3,29.1,26.0,22.7,16.9$, 16.0, $14.1 \mathrm{ppm}$; HRMS (TOF-ESI): $\mathrm{m} / z$ calcd for $\mathrm{C}_{39} \mathrm{H}_{57} \mathrm{BF}_{2} \mathrm{I}_{2} \mathrm{~N}_{2} \mathrm{O}_{2} \mathrm{Na}$ : $910.2505[M+\mathrm{Na}]^{+}$; found: $910.2495[M+\mathrm{Na}]^{+}$. 
4,4-Difluoro-8-[3',5'-bis(decyloxy)phenyl $]-2-\left[p-\left(2^{\prime \prime}, 2^{\prime \prime \prime}, 6^{\prime \prime \prime}, 2^{\prime \prime \prime \prime}-\right.\right.$-terpyridin$4^{\prime \prime}$-yl)ethynylphenyl]-1,3,5,7-tetramethyl-4-bora-3a,4a-diaza-s-indacene (5): Compound 3 (0.30 mmol, $0.23 \mathrm{~g})$, 4'-ethynyl-2,2';6'2'-terpyridine $(0.60 \mathrm{mmol}, \quad 0.20 \mathrm{~g}), \quad\left[\mathrm{PdCl}_{2}\left(\mathrm{PPh}_{3}\right)_{2}\right] \quad(0.018 \mathrm{mmol}, \quad 12.64 \mathrm{mg}), \quad \mathrm{CuI}$ $(0.03 \mathrm{mmol}, 5.71 \mathrm{mg})$, and freshly distilled THF $(10 \mathrm{~mL})$ were added to a $50 \mathrm{~mL}$ Schlenk tube. Diisopropylamine $(5 \mathrm{~mL})$ was added and the resulting suspension was extensively deaerated by bubbling with argon at $50^{\circ} \mathrm{C}$ for $40 \mathrm{~min}$. The reaction mixture was stirred at room temperature for $1 \mathrm{~d}$. The solvent was removed under reduced pressure and the residue was washed with water $(100 \mathrm{~mL})$ and extracted into $\mathrm{CHCl}_{3}$. The organic layer was evaporated and column chromatographic separation of the residue on neutral alumina using 1:1 $\mathrm{CHCl}_{3} /$ hexane as the eluant gave $\mathbf{5}$ as a purple solid. (0.203 g, $70 \%) .{ }^{1} \mathrm{H}$ NMR $\left(400 \mathrm{MHz}, \mathrm{CDCl}_{3}\right): \delta=8.67(2 \mathrm{H}$,

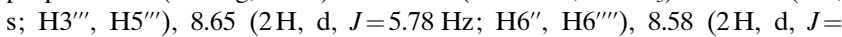

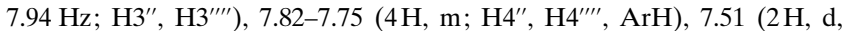
$J=8.23 \mathrm{~Hz}$; ArH), 7.30-7.25 (2 H, m; H5", H5"'"'), 6.48 (1 H, s; H4'), 6.37 $\left(2 \mathrm{H}, \mathrm{d}, J=1.93 \mathrm{~Hz} ; \mathrm{H} 2^{\prime}, \mathrm{H}^{\prime}\right), 5.97(1 \mathrm{H}, \mathrm{s} ; \mathrm{H} 6), 3.87(4 \mathrm{H}, \mathrm{t}, J=6.57 \mathrm{~Hz}$; $\left.\mathrm{OCH}_{2}\right), 2.66\left(3 \mathrm{H}, \mathrm{s} ; \mathrm{CH}_{3}\right), 2.52\left(3 \mathrm{H}, \mathrm{s} ; \mathrm{CH}_{3}\right), 1.73-1.63\left(4 \mathrm{H}, \mathrm{m} ; \mathrm{CH}_{2}\right)$, $1.65\left(3 \mathrm{H}, \mathrm{s} ; \mathrm{CH}_{3}\right), 1.52\left(3 \mathrm{H}, \mathrm{s} ; \mathrm{CH}_{3}\right), 1.40-1.30\left(4 \mathrm{H}, \mathrm{m} ; \mathrm{CH}_{2}\right), 1.20(24 \mathrm{H}$, $\left.\mathrm{s} ; \mathrm{CH}_{2}\right), 0.80 \mathrm{ppm}\left(6 \mathrm{H}, \mathrm{t}, J=6.63 \mathrm{~Hz} ; \mathrm{CH}_{3}\right) ;{ }^{13} \mathrm{C} \mathrm{NMR}(100 \mathrm{MHz}$, $\left.\mathrm{CDCl}_{3}\right): \delta=161.3,156.1,156.0,149.4,149.1,137.7,137.0,136.1,131.7$, $127.2,124.5,123.9,121.4,118.6,106.2,102.4$, 95.6, 83.8, 68.5, 31.9, 29.6, 29.5, 29.4, 29.3, 29.2, 26.0, 22.7, 14.8, $14.1 \mathrm{ppm}$; HRMS (TOF-ESI): $\mathrm{m} / \mathrm{z}$ calcd for $\mathrm{C}_{62} \mathrm{H}_{72} \mathrm{BF}_{2} \mathrm{~N}_{5} \mathrm{O}_{2} \mathrm{Na}$ : $989.5661[M+\mathrm{Na}]^{+}$; found: 989.5676 $[M+\mathrm{Na}]^{+}$

4,4-Difluoro-8-[3',5'-bis(decyloxy)phenyl]-2,6-bis $\left[p-\left(2^{\prime \prime}, 2^{\prime \prime \prime}, 6^{\prime \prime \prime}, 2^{\prime \prime \prime \prime}\right.\right.$-terpyridin-4"-yl)ethynylphenyl]-1,3,5,7-tetramethyl-4-bora-3a,4a-diaza-s-indacene (7): Compound 4 (0.338 mmol, $0.30 \mathrm{~g})$, 4'-ethynyl-2,2';6'2"-terpyridine $(1.182 \mathrm{mmol}, 0.394 \mathrm{~g}),\left[\mathrm{PdCl}_{2}\left(\mathrm{PPh}_{3}\right)_{2}\right](0.0203 \mathrm{mmol}, 14.23 \mathrm{mg}), \mathrm{CuI}$ $(0.034 \mathrm{mmol}, 6.44 \mathrm{mg})$, and freshly distilled THF $(10 \mathrm{~mL})$ were added to a $50 \mathrm{~mL}$ Schlenk tube. Diisopropylamine $(5 \mathrm{~mL})$ was added and the resulting suspension was extensively deaerated by bubbling with argon at $50^{\circ} \mathrm{C}$ for $40 \mathrm{~min}$. After degassing, the reaction mixture was stirred at room temperature for $1 \mathrm{~d}$. Solvents were removed under reduced pressure and the residue was washed with water $(100 \mathrm{~mL})$ and extracted into $\mathrm{CHCl}_{3}$. The organic layer was evaporated and separation by column chromatography on neutral alumina using $1: 1 \quad \mathrm{CHCl}_{3} /$ hexane as the eluant gave 7 as a blue solid. (0.382 g, 87\%). ${ }^{1} \mathrm{H}$ NMR (400 MHz, $\left.\mathrm{CDCl}_{3}\right): \delta=8.68\left(4 \mathrm{H}, \mathrm{s} ; \mathrm{H}^{\prime \prime \prime}, \mathrm{H} 5^{\prime \prime \prime}\right), 8.64\left(4 \mathrm{H}, \mathrm{d}, J=6.55 \mathrm{~Hz} ; \mathrm{H} 6^{\prime \prime}\right.$, $\left.\mathrm{H}^{\prime \prime \prime \prime}\right), 8.61$ (4H, d, $J=7.94 \mathrm{~Hz}$; H3" $\left.\mathrm{H}^{\prime \prime \prime \prime}\right), 7.86-7.79\left(4 \mathrm{H}, \mathrm{m} ; \mathrm{H} 4^{\prime \prime}\right.$, $\left.\mathrm{H}^{\prime \prime \prime \prime}\right), 7.82(4 \mathrm{H}, \mathrm{d}, J=8.03 \mathrm{~Hz} ; \mathrm{ArH}), 7.52(4 \mathrm{H}, \mathrm{d}, J=8.15 \mathrm{~Hz} ; \mathrm{ArH})$, 7.33-7.27 (4H, m; H5", H5"'"') $6.52(1 \mathrm{H}$, brs; H4') $6.39(2 \mathrm{H}, \mathrm{d}, J=$ $\left.1.78 \mathrm{~Hz} ; \mathrm{H}^{\prime}, \mathrm{H}^{\prime}\right), 3.88\left(4 \mathrm{H}, \mathrm{t}, J=6.52 \mathrm{~Hz} ; \mathrm{OCH}_{2}\right), 2.68\left(6 \mathrm{H}, \mathrm{s} ; \mathrm{CH}_{3}\right)$, 1.74-1.64 (4H, m; $\left.\mathrm{CH}_{2}\right), 1.69\left(6 \mathrm{H}, \mathrm{s} ; \mathrm{CH}_{3}\right), 1.43-1.33\left(4 \mathrm{H}, \mathrm{m} ; \mathrm{CH}_{2}\right), 1.20$ $\left(24 \mathrm{H}, \mathrm{s} ; \mathrm{CH}_{2}\right), 0.80 \mathrm{ppm}\left(6 \mathrm{H}, \mathrm{t}, J=5.26 \mathrm{~Hz} ; \mathrm{CH}_{3}\right) ;{ }^{13} \mathrm{C} \mathrm{NMR}(100 \mathrm{MHz}$, $\left.\mathrm{CDCl}_{3}\right): \delta=161.4,156.2,155.9,149.3,149.1,141.0,137.7,136.9,132.1$, $132.0,131.9,131.6,131.1,128,6,128.4,127.2,124.2,123.9,121.4,118.6$, $106.2,96.4,83.0,68.5,31.9,29.6,29.4,29.3,29.2,26.0,22.7,14.1$, $13.9 \mathrm{ppm}$; HRMS (MALDI-TOF): $\mathrm{m} / z$ calcd for $\mathrm{C}_{85} \mathrm{H}_{85} \mathrm{BF}_{2} \mathrm{~N}_{8} \mathrm{O}_{2}$ : $1298.686[M]^{+}$; found: $1298.830[M]^{+}$

$5,5^{\prime}$-Bis $\left[4^{\prime \prime}, 4^{\prime \prime}\right.$-difluoro-8"-(3"',5"'-bis(decyloxy)phenyl $]-1^{\prime \prime}, 3^{\prime \prime}, 5^{\prime \prime}, 7^{\prime \prime}$-tetramethyl-4"-bora-3" a,4"a-diaza-s-indacene-2"'-ethynyl-2,2'-bipyridine (6): Compound $\mathbf{3} \quad(0.265 \mathrm{mmol}, \quad 0.202 \mathrm{~g}), \quad 5,5^{\prime}$-diethynyl-2,2'-bipyridine $(0.0256 \mathrm{mmol}, \quad 18 \mathrm{mg}), \quad\left[\mathrm{PdCl}_{2}\left(\mathrm{PPh}_{3}\right)_{2}\right] \quad(0.032 \mathrm{mmol}, \quad 22.3 \mathrm{mg}), \quad \mathrm{CuI}$ $(0.0265 \mathrm{mmol}, 5.05 \mathrm{mg})$, and freshly distilled THF $(10 \mathrm{~mL})$ were added to a $50 \mathrm{~mL}$ Schlenk tube. Diisopropylamine $(5 \mathrm{~mL})$ was added and the resulting suspension was extensively deaerated by bubbling with argon at $50^{\circ} \mathrm{C}$ for $40 \mathrm{~min}$. After degassing, the reaction mixture was stirred at $50^{\circ} \mathrm{C}$ for $1 \mathrm{~d}$. After removal of the solvents under reduced pressure, the residue was washed with water $(100 \mathrm{~mL})$ and extracted into $\mathrm{CHCl}_{3}$. The organic layer was evaporated and separation by column chromatography on silica gel using $\mathrm{CHCl}_{3}$ as the eluant gave $\mathbf{6}$ as a purple solid $(0.215 \mathrm{~g}$, $55 \%) .{ }^{1} \mathrm{H}$ NMR $\left(400 \mathrm{MHz}, \mathrm{CDCl}_{3}\right): \delta=8.65\left(2 \mathrm{H}, \mathrm{d}, J_{H 6-H 4}=1.44 \mathrm{~Hz} ; \mathrm{H} 6\right.$, $\left.\mathrm{H}^{\prime}\right), 8.28\left(2 \mathrm{H}, \mathrm{d}, J_{\mathrm{H} 3-H 4}=8.28 \mathrm{~Hz} ; \mathrm{H} 3, \mathrm{H}^{\prime}\right), 7.73\left(2 \mathrm{H}, \mathrm{dd}, J_{H 4-H 3}=8.28\right.$, $\left.J_{H 4-H 6}=1.04 \mathrm{~Hz} ; \mathrm{H} 4, \mathrm{H} 4^{\prime}\right), 6.47\left(2 \mathrm{H}, \mathrm{t}, J=2.20 \mathrm{~Hz} ; \mathrm{H}^{\prime \prime \prime}\right), 6.32(4 \mathrm{H}, \mathrm{d}$, $J=2.20 \mathrm{~Hz}$; H2"', H6"'), $5.98\left(2 \mathrm{H}, \mathrm{s} ; \mathrm{H} 2^{\prime \prime}\right), 3.82(8 \mathrm{H}, \mathrm{t}, J=6.62 \mathrm{~Hz}$; $\left.\mathrm{OCH}_{2}\right), 2.63\left(6 \mathrm{H}, \mathrm{s} ; \mathrm{CH}_{3}\right), 2.50\left(6 \mathrm{H}, \mathrm{s} ; \mathrm{CH}_{3}\right), 1.71-1.61\left(8 \mathrm{H}, \mathrm{m} ; \mathrm{CH}_{2}\right)$, $1.60\left(6 \mathrm{H}, \mathrm{s} ; \mathrm{CH}_{3}\right), 1.52\left(6 \mathrm{H}, \mathrm{s} ; \mathrm{CH}_{3}\right), 1.38-1.29\left(8 \mathrm{H}, \mathrm{m} ; \mathrm{CH}_{2}\right), 1.20(48 \mathrm{H}$, brs; $\left.\mathrm{CH}_{2}\right), 0.78 \mathrm{ppm}\left(12 \mathrm{H}, \mathrm{t}, J=5.28 \mathrm{~Hz} ; \mathrm{CH}_{3}\right) ;{ }^{13} \mathrm{C} \mathrm{NMR}(100 \mathrm{MHz}$,
$\left.\mathrm{CDCl}_{3}\right): \delta=161.3,158.0,156.2,153.9,151.2,145.5,142.2,138.7,136.0$ $132.6,129.9,122.2,120.5,114.1,106.2,102.5,93.1,87.1,68.5,31.9,29.7$ 29.5, 29.3, 29.2, 29.1, 26.0, 22.7, 14.8, 13.5 ppm; HRMS (MALDI-TOF): $m / z$ calcd for $\mathrm{C}_{92} \mathrm{H}_{122} \mathrm{~B}_{2} \mathrm{~F}_{4} \mathrm{~N}_{6} \mathrm{O}_{4}: 1472.965[M]^{+}$; found: $1473.120[M]^{+}$

4,4-Difluoro-8-[3',5'-bis(decyloxy)phenyl]-2,6-bis (2" ,2'"'-bipyridine-5"'-ethynyl)-1,3,5,7-tetramethyl-4-bora-3a,4a-diaza-s-indacene (8): Compound 4 (0.161 mmol, $143 \mathrm{mg})$, 5-ethynyl-2,2'-bipyridine (0.972 mmol, $175 \mathrm{mg})$, $\left[\mathrm{PdCl}_{2}\left(\mathrm{PPh}_{3}\right)_{2}\right](0.096 \mathrm{mmol}, 6.74 \mathrm{mg}), \mathrm{CuI}(0.016 \mathrm{mmol}, 3 \mathrm{mg})$, and freshly distilled THF $(10 \mathrm{~mL})$ were added to a $50 \mathrm{~mL}$ Schlenk tube. Diisopropylamine $(5 \mathrm{~mL})$ was added and resulting suspension was extensively deaerated by bubbling with argon at $50^{\circ} \mathrm{C}$ for $40 \mathrm{~min}$. After degassing, the reaction mixture was stirred at $40^{\circ} \mathrm{C}$ for $1 \mathrm{~d}$. After removal of the solvents under reduced pressure, the residue was washed with water $(100 \mathrm{~mL})$ and extracted into $\mathrm{CHCl}_{3}$. The solvent was removed and separation by column chromatography on silica gel using $1 \%$ methanol/ $\mathrm{CHCl}_{3}$ as the eluant gave 8 as a blue solid. $(0.128 \mathrm{~g}, 80 \%) .{ }^{1} \mathrm{H}$ NMR $\left(400 \mathrm{MHz}, \mathrm{CDCl}_{3}\right): \delta=8.68\left(2 \mathrm{H}, \mathrm{s} ; \mathrm{H}^{\prime \prime}\right), 8.61\left(2 \mathrm{H}, \mathrm{d}, J=4.52 \mathrm{~Hz} ; \mathrm{H} 6^{\prime \prime \prime}\right)$, 8.40-8.30 (4H, m; H3", H3 $\left.{ }^{\prime \prime \prime}\right), 7.80-7.75$ (4H, m; H4", H4"'), 7.30-7.20 $\left(2 \mathrm{H}, \mathrm{m} ; \mathrm{H} 5^{\prime \prime}, \mathrm{H} 5^{\prime \prime \prime}\right), 6.51\left(1 \mathrm{H}, \mathrm{s} ; \mathrm{H} 4^{\prime}\right), 6.38\left(2 \mathrm{H}, \mathrm{d}, J=1.63 \mathrm{~Hz} ; \mathrm{H} 2^{\prime}\right.$, $\left.\mathrm{H}^{\prime}\right), 3.88\left(4 \mathrm{H}, \mathrm{t}, J=6.54 \mathrm{~Hz} ; \mathrm{OCH}_{2}\right), 2.68\left(6 \mathrm{H}, \mathrm{s} ; \mathrm{CH}_{3}\right), 1.74-1.64(4 \mathrm{H}$, $\left.\mathrm{m} ; \mathrm{CH}_{2}\right), 1.67\left(6 \mathrm{H}, \mathrm{s} ; \mathrm{CH}_{3}\right), 1.41-1.31\left(4 \mathrm{H}, \mathrm{m} ; \mathrm{CH}_{2}\right), 1.20(24 \mathrm{H}$, brs; $\left.\mathrm{CH}_{2}\right), 0.79 \mathrm{ppm}\left(6 \mathrm{H}, \mathrm{t}, J=6.19 \mathrm{~Hz} ; \mathrm{CH}_{3}\right) ;{ }^{13} \mathrm{C} \mathrm{NMR}\left(100 \mathrm{MHz}, \mathrm{CDCl}_{3}\right)$ : $\delta=161.4,159.2,155.9,153.0,151.3,149.3,145.3,143.1,140.6,138.9,135.9$ 131.5, 124.2, 121.4, 120.4, 116.2, 106.0, 102.7, 93.5, 86.0, 68.5, 31.9, 29.5, 29.4, 29.3, 29.1, 26.0, 22.7, 14.1, 13.8, 13.4 ppm; HRMS (MALDI-TOF): $m / z$ calcd for $\mathrm{C}_{63} \mathrm{H}_{71} \mathrm{BF}_{2} \mathrm{~N}_{6} \mathrm{O}_{2}$ : $992.570[M]^{+}$; found: $992.741[M]^{+}$.

\section{Acknowledgements}

The authors gratefully acknowledge support from Scientific and Technological Research Council of Turkey (TUBITAK), grant number TBAG108T212, and Turkish Academy of Sciences (TUBA).

[1] M. Ruben, J. Rojo, F. J. Romero-Salguero, L. H. Uppadine, J.-M. Lehn, Angew. Chem. 2004, 116, 3728-3747; Angew. Chem. Int. Ed. 2004, 43, 3644-3662.

[2] J.-M. Lehn, Polym. Int. 2002, 51, 825-839.

[3] L. Brunsveld, B. J. B. Folmer, E. W. Meijer, R. P. Sijbesma, Chem Rev. 2001, 101, 4071-4098.

[4] R. Dobrawa, F. Würthner, J. Polym. Sci. Part-A: Polym. Chem. 2005, 43, 4981-4995.

[5] B. J. B. Folmer, R. P. Sijbesma, R. M. Versteegen, J. A. J. van der Rijt, E. W. Meijer, Adv. Mater. 2000, 12, 874-878.

[6] R. P. Sijbesma, F. H. Beijer, L. Brunsveld, B. J. B. Folmer, J. H. K. K. Hirschberg, R. F. M. Lange, J. K. L. Lowe, E. W. Meijer, Science 1997, 278, 1601-1604.

[7] Q. Chu, Y. Pang, J. Polym. Sci. Part-A: Polym. Chem. 2006, 44, 2338-2345.

[8] Y.-Y. Chen, Y.-T. Tao, H.-C. Lin, Macromolecules 2006, 39, 85598566.

[9] S.-C. Yu, C.-C. Kwok, W.-K. Chan, C.-M. Che, Adv. Mater. 2003, 15 , 1643-1647.

[10] R. Dobrawa, M. Lysetska, P. Ballester, M. Grüne, F. Würthner, Macromolecules 2005, 38, 1315-1325.

[11] K. Ogawa, Y. Kobuke, Angew. Chem. 2000, 112, 4236-4239; Angew. Chem. Int. Ed. 2000, 39, 4070-4073.

[12] J. B. Beck, S. J. Rowan, J. Am. Chem. Soc. 2003, 125, 13922-13923.

[13] F. Würthner, Chem. Commun. 2004, 1564-1579.

[14] R. Dobrawa, M. Lysetska, P. Ballester, M. Grüne, F. Würthner, Macromolecules 2005, 38, 1315-1325.

[15] C.-C. You, R. Dobrawa, C. R. Saha-Möller, F. Würthner, Top. Curr. Chem. 2005, 258, 39-82.

[16] M. Chiper, M. A. R. Meier, D. Wouters, S. Hoeppener, C.-A. Fustin, J.- F. Gohy, U. S. Schubert, Macromolecules 2008, 41, 2771-2777. 
[17] C. Ott, B. G. G. Lohmeijer, D. Wouters, U. S. Schubert, Macromol. Chem. Phys. 2006, 207, 1439-1449.

[18] R. P. Haugland, The Handbook-A Guide to Fluorescent Probes and Labeling Technologies, 10th ed., Invitrogen Corporation, Eugene, OR (USA), 2005.

[19] A. Treibs, F. H. Kreuzer, Justus Liebigs Ann. Chem. 1968, 718, $208-$ 223.

[20] A. Loudet, K. Burgess, Chem. Rev. 2007, 107, 4891-4932.

[21] R. Ziessel, G. Ulrich, A. Harriman, New J. Chem. 2007, 31, 496501.

[22] R. Ziessel, Compt. Rend. Chim. 2007, 10, 622-629.

[23] G. Ulrich, R. Ziessel, A. Harriman, Angew. Chem. 2008, 120, $1202-$ 1219; Angew. Chem. Int. Ed. 2008, 47, 1184-1201.

[24] A. Coskun, E. U. Akkaya, J. Am. Chem. Soc. 2005, 127, $10464-$ 10465.

[25] K. Rurack, M. Kollmannsberger, U. Resch-Genger, J. Daub, J. Am. Chem. Soc. 2000, 122, 968-969.

[26] A. Coskun, E. U. Akkaya, J. Am. Chem. Soc. 2006, 128, $14474-$ 14475.

[27] L. Zeng, E. W. Miller, A. Pralle, E. Y. Isacoff, C. J. Chang, J. Am. Chem. Soc. 2006, 128, 10-11.

[28] A. Coskun, E. Deniz, E. U. Akkaya, Org. Lett. 2005, 7, 5187-5189.

[29] F. Camerel, L. Bonardi, G. Ulrich, L. Charbonniere, B. Donnio, C. Bourgogne, D. Guillon, P. Retailleau, R. Ziessel, Chem Mater. 2006, $18,5009-5021$.
[30] S. Hattori, K. Ohkubo, Y. Urano, H. Sunahara, T. Nagano, Y. Wada, T. V. Tkachenko, H. Lemmetyinen, S. Fukuzumi, J. Phys. Chem. B 2005, 109, 15368-15375.

[31] S. Erten-Ela, M. D. Yilmaz, B. Icli, Y. Dede, S. Icli, E. U. Akkaya, Org. Lett. 2008, 10, 3299-3302.

[32] Q. Zheng, G. Xu, P. N. Prasas, Chem. Eur. J. 2008, 14, 5812-5819.

[33] S. Atilgan, Z. Ekmekci, A. L. Dogan, D. Guc, E. U. Akkaya, Chem. Commun. 2006, 4398-4400.

[34] A. Gorman, J. Killoran, C. O’Shea, T. Kenna, W. M. Gallagher, D. F. O'Shea, J. Am. Chem. Soc. 2004, 126, 10619-10631.

[35] B. Turfan, E. U. Akkaya, Org. Lett. 2001, 3, 2857-2859.

[36] G. Ulrich, R. Ziessel, Tetrahedron Lett. 2004, 45, 1949-1953.

[37] C. Goze, G. Ulrich, L. Charbonniere, M. Cesario, T. Prange, R. Ziessel, Chem. Eur. J. 2003, 9, 3748-3755.

[38] G. Ulrich, R. Ziessel, J. Org. Chem. 2004, 69, 2070-2083.

[39] G. Ulrich, R. Ziessel, Synlett 2004, 439-444.

[40] Y. Yogo, Y. Urano, Y. Ishitsuka, F. Maniwa, T. Nagano, J. Am. Chem. Soc. 2005, 127, 12162-12163.

[41] V. Grosshenny, F. M. Romero, R. Ziessel, J. Org. Chem. 1997, 62, $1491-1500$

[42] C. Goze, G. Ulrich, R. Ziessel, Org. Lett. 2006, 8, 4445-4448.

[43] S. Sreejith, K. P. Divya, A. Ajayaghosh, Chem. Commun. 2008 2903-2905.

Received: December 4, 2008 Published online: February 19, 2009 